\title{
Vállalkozások károsanyag-kibocsátás csökkentésének lehetőségei
}

Zsuzsa Gál: The possibilities of companies how to reduce their emmisions

Summary

The sustainability and its key element, the environmental awareness has been known for decades, however in general can be said that in the decision making the short term economic profit is still more dominant both on the individual and company levels. In last few years the rapid growth of $\mathrm{CO}_{2}$ emission is now not just risking the human life but the flora and fauna is in heavy danger. The concerns pay more attention on their short-term profits instead of the environmental protection. First of all with the change of the leadership attitude can reach the environmentally conscious organization that can support the reduction of the emissions, so the improvement of the atmospherical $\mathrm{CO}_{2}$ concentration.

In my study I'm going to present what possibilities do the companies have to reduce their emissions and how these improvements could be harmonized with the profit interests (with the reduce of electricity-, water-, and gas consumption).

Keywords: sustainability, environmental protection, reduction of the emissions, compnay level

\section{ÖSSZEFOGLALÓ}

A fenntarthatóság, és annak lényegi eleme, a környezettudatosság fogalma bár már több évtizedes múlttal rendelkezik, általánosságban mégis elmondható, hogy a rövid távú gazdasági profit érdekek még mindig dominánsabban jelennek meg a döntéshozatalban, mind egyéni mind vállalati szinten. A fenntarthatóság irányába való haladás miatt pozitív hatást jelentene, ha a különböző ágazatok, és az ágazatokban tevékenykedő vállalatok is tudatos lépéseket tennének annak érdekében, hogy csökkentsék a környezeti terhelésüket.

A téma fontosságát támasztja alá az elmúlt évszázadokban bekövetkezett jelentős klímaváltozás, a légköri szén-dioxid koncentráció rohamos növekedése, a globális felmelegedés, melyeknek következtében nem csak a népesség egészségi állapota forog kockán, hanem a növény-és állatvilág is jelentős veszélybe került. Fontosnak tartom, hogy a lehetőségek számbavételével igyekezzünk javítani a jelenlegi helyzeten, globális, szervezeti, de akár egyéni szinten is.
Általánosságban elmondható, hogy a vállalkozások vezetői kevésbé elkötelezettek a fenntarthatóság iránt, és környezeti attitúdjük elmarad attól a szinttől, ahol érdemben lehet tenni a környezetterhelés csökkentéséért. A környezeti attitűd hiányában az alkalmazottak ösztönzése, ismereteinek bővítése is elmarad, így az egyéni felelősségvállalás szerepe csökken. Saját felmérésem eredményei igazolják, hogy a környezettudatosan múködő vállalkozás hatással lehet az egyén saját háztartásának környezettudatos múködtetésére is, a munkahelyen végzett környezettudatos tevékenységekből (például szelektív hulladékgyűjtés, energiatakarékosság, víztakarékosság) a hétköznapi gyakorlatba is ültetnek át a munkavállalók bizonyos tevékenységeket. Egy szervezet környezetbarát működése tehát hosszú távon nem csupán a szervezeti kibocsátást képes csökkenteni, hanem hatással tud lenni az egyénre, amely által a háztartások kibocsátását is képes csökkenteni.

A fent említett okok miatt tartom érdemesnek feltérképezni, hogy a különböző vállalkozásoknak, méretüktől függően, és attól függetlenül is, milyen lehetőségek állnak rendelkezésükre a 
fenntartható múködés érdekében, továbbá amennyiben a gazdasági érdekek elótérbe helyezését megváltoztatni nem lehet, hogyan lehet a profit érdekekkel összehangolni a környezettudatos irányítást. Ugyanis egy nagyobb telephely esetén már a fenntartás is nagymértékű energiafelhasználással jár, az üzemeltetés pedig még tovább növeli a víz-, áram- és gázfelhasználást, így az ezekkel való gazdálkodás költségmegtakarítási szempontból is lényeges, de a környezetre való negatív hatás csökkentése miatt is nagyon fontos.

A tanulmányban a szakirodalmi áttekintést követően röviden bemutatom, hogy milyen tevékenységekben tudják a vállalkozások mérettől függetlenül a fenntarthatóság elveit követni, illetve méretüktől függően milyen korlátok, és milyen lehetőségek állnak rendelkezésükre. Kitérek arra is, hogyan találkoznak a fenntarthatóság elvei a már korábban említett rövid távú gazdasági profit érdekekkel.

Kulcsszavak: fenntartahtóság, környezettudatosság, környezetterhelés, vállalkozások

\section{BEVEZETÉS}

Napjainkra az emberiségnek számos környezeti problémával kell szembenéznie, az ökoszféra állapota pedig egyre gyorsuló ütemben romlik. A túllövés ${ }^{1}$ állapotába értünk, amelynek fő oka a folyamatos növekedés (népesség, az élelmiszer-termelés, az ipari termelés, az erőforrások felhasználása és ezáltal a szennyezés is), és átléptünk bizonyos határokat, természeti korlátokat. (Schäfferné, 2008)

A környezeti problémák mérséklésében a környezettudatosságnak fontos szerepe van, amelyben jellemző magatartásforma az egyén felelős viselkedése a környezet védelmével kapcsolatos feladatok megoldásában, a természeti értékek megőrzésében. (Medvéné, 2013)

A szervezetek fenntarthatóság irányába történő elmozdulása az 1950-es, 1960-as években kezdődött a társadalmi felelősségvállalás tárgyalásával az Amerikai Egyesült Államokban,

${ }^{1}$ Az a jelenség, amely ahhoz köthető, amikor az emberiség túllépi a rendelkezésre álló természeti erőforrások szabta keretet. azonban a témával intenzíven csak a 70-es években kezdtek foglalkozni a szervezetkutatók. (Csigéné, 2008)

Az 1980-as években már egyre több kutatás foglalkozott a társadalmi felelősségvállalás témakörével. A 90-es évek végén az Üzleti Világtanács a Fenntartható Fejlődésért (WBCSD) a vállalatok társadalmi felelősségvállalását a következőképpen fogalmazta meg: „A vállalatok társadalmi felelősségvállalása a vállalat folyamatos elkötelezettsége az etikus viselkedésre és a gazdasági fejlödéshez való hozzájárulása, miközben a munkavállalói és családjuk, valamint a helyi közösségek és a tágabb társadalom életminőségét javítja."

(World Business Council For Sustainable Development - Corporate Social Responsibility (1999)- Meeting changing expectations, p.3.)

Az ezredforduló környékén az Európai Bizottság zöld könyvében megjelent a vállalati társadalmi felelősségvállalás definíciója, amely összhangban a Brundtland Bizottság fenntartható fejlődésről alkotott meghatározásával a vállalati társadalmi felelősségvállalást a következőképpen definiálja:

„A vállalati társadalmi felelösségvállalás olyan törekvés, melynek értelmében a vállalatok önkéntes alapon üzleti tevékenységükbe integrálnak társadalmi és környezetvédelmi célkitüzéseket is, és ezen elvek mentén alakítják kapcsolataikat érintettjeikkel." (Európa Bizottság, 2001)

2011-ben az Európa Bizottság bővített meghatározásából már hiányzik az önkéntes kifejezés, a társadalmi felelősségvállalást a vállalkozásoknak a társadalomra gyakorolt hatásuk iránti felelősségként értelmezi, ezzel nagyobb hangsúlyt helyez a vállalkozások átláthatóságára, és törekszik a magánszféra fokozottabb bevonására a környezeti és társadalmi problémák megoldásába.

Látható, hogy a vállalati társadalmi felelősségvállalás értelmezése széles skálán mozog, évről évre bővül jelentéstartalma, és egyre fontosabb szerepet kap ezen tevékenységben a társadalom, a környezetvédelem, a környezet iránti elkötelezettség. Ezáltal kerül mind inkább előtérbe az egyéni és társadalmi környezeti tudat 
növelése, a jogszabályoknak való megfelelés fontossága, és ezáltal az egységességre törekvés, a szabványosítás.

A környezettudatosság több szintű értelmezését figyelembe véve megkülönböztetünk globális, nemzeti, szervezeti és egyéni szintű környezettudatosságot. A témához szorosan kapcsolódó szervezeti szinthez soroljuk a nonprofit szervezeteket, profitorientált gazdálkodó szervezeteket a tudományos élet szervezeteit. A szervezetek esetében a környezettudatosság megnyilvánulása széles skálán mozog, de az elkötelezettség alapvetően a vállalat szempontjából releváns környezeti kérdések fontosságának felismerésével, és a stratégiai tervbe való integrálással fejeződik ki. A fogyasztói környezettudatosság sajátos viselkedésmód a környezethasználat csökkentéséért (középpontjában a tudatos vásárlás, az autóhasználat optimalizálása, a szelektív hulladékgyújtés, az energiatakarékosság). Az egyéni környezettudatosság a fogyasztó speciális világnézete, értékrendszere és hiedelemrendszere, amely szerint fontosnak tartja a környezetet és a környezeti problémákat, illetve azok megoldásait. (Schäfferné, 2008) Napjainkban egyre jelentősebbé válik a felelős vállalati magatartás, amely nem csupán példamutatásként szolgál, hanem egyrészt piaci előnyt jelent, más részről pedig egyre inkább egyfajta elvárás az ügyfelek részéről. Ugyanis a tulajdonosok számára nagyobb kockázatot jelent a vállalat iránti bizalom meggyengülése, mint a rövid távon költségesnek, hosszú távon azonban mindenképp megtérülőnek bizonyuló felelősségvállalás. Ennek tudatosítása a tulajdonosokkal és döntéshozókkal alapvető fontosságú. Ezen felül a vállalatok egyre fontosabb szereplőivé válnak a társadalomnak, hiszen mindenütt jelen vannak Tóth, 2007).

Összességében véve megállapítható, hogy egy vállalat szociálisan felelős beállítódása hosszabb távon felfogható egy stratégiai jellegű beruházásnak, a jövőbe való invesztálásnak is. Valószínúsíthető, sőt az eddigi tapasztalatok, felmérések alapján bizton is állítható, hogy az ilyen magatartásminták felvétele végső soron direkt gazdasági hatással is bír. Emellett távlatokban egy olyan "win-win" jellegú helyzetet teremt- het, amelyből mind a vállalat, mind a környezete és a társadalom profitálhat. (Medvéné, 2013) A világ egy évtizede ott tartott, hogy az integrált szennyezés-megelőzés elveit átültette a gyakorlatba (ezt célozta az EU IPCC direktívája, ENSZ tisztább termelési projektjei). A XXI. század kapujában nem látott tovább a vállalati szektor a csővégi technológiánál, napjainkban azonban az öko-hatékonyság, újrahasznosítás, javítás fejlődési szakaszában és az újratervezés kapujában állunk. A környezetvédelmi intézkedésekkel párhuzamosan azonban a környezeti terhelés nem csökkent, sokkal inkább növekvő tendenciát mutat a növekvő népesség, szükséglet, és fogyasztás következtében. A szigorúan monoton növekvő környezeti terhelés kérdésköre egyre inkább foglalkoztatja a kutatókat. Olyan problémákra keresnek kérdést, mint például, hogyan tegyünk eleget a növekvő népesség növekvő igényeinek, erőforrásaink túlhasználata nélkül.

\section{KÖRNYEZETTUDATOS VÁLLALATIRÁNYÍTÁS LEHETŐSÉGEI}

A következőkben röviden ismertetésre kerülnek azon tevékenységek, amelyek lehetőséget kínálnak a szervezetek számára a környezettudatos irányításra. Ezen tevékenységek egy része anyagi ráfordításokkal jár, profitnövelő hatása csak közvetetten érvényesül, azonban vannak olyan tevékenységek köztük, amelyek megfelelő keretek között képesek közvetlenül is profitot termelni a szervezetnek. A kapocs a fenntartható szervezetirányítás és a rövid távú gazdasági profitérdekek előtérbe helyezése között ezen tevékenységekben rejlik.

Tisztább termelés: A tisztább termelés lényege, hogy a nyersanyagok hatékonyabb felhasználását, az emissziók forrásuknál történő csökkentését igyekeznek elérni. Ez megvalósulhat hatékonyságnövelés révén (azaz a fajlagos nyersanyag- és energiafelhasználás csökkentésén keresztül), illetve az ún. gondosabb bánásmód érvényesítésén keresztül, amely nem jár jelentős beruházásigénnyel, nagyobb odafigyeléssel, takarékossággal, az előírások betartásával jelentősebb veszteségek kerülhetőek el. 
Hulladék-minimalizálás: Összhangban a tisztább termelés, gondos bánásmód érvényesítésével a hulladék-minimalizálás lényege a takarékosság, nagyobb odafigyelés, az előírások betartása, amelynek célja a keletkezett hulladékok menynyiségének csökkentése (akár újrahasznosítás, vagy a zárt láncban gondolkodás révén), a selejt termékek keletkezésének minél nagyobb mértékű visszaszorítása.

Környezeti kommunikáció: a nagyobb szervezetek esetén jellemző a környezeti jelentés, fenntarthatósági jelentés, környezeti kézikönyv készítése, amely tartalmazza az adott szervezet környezeti politikáját, felelősségvállalását a környezeti terhelés csökkentésére, a tevékenységéből adódó potenciális veszélyforrásokat, az azok csökkentésére irányuló törekvéseit. Konkrét célokat jelöl ki, akár stratégiai terveket is füzhet hozzájuk a szervezet irányítása, amelyeknek megvalósítása révén a környezeti terhelés hosszabb távon is csökkenthető lehet.

Életciklus-elemzés: A gyártás, vagy folyamat során felhasznált energia, nyersanyag és a környezetbe bocsátott emissziók minőségi és mennyiségi meghatározásával kezdődik. Ezen adatok alapján lehet felbecsülni a termék, vagy folyamat környezeti hatását, értékelni és a környezeti fejlesztés lehetőségét felmérni. Mivel az életciklus-elemzés a termék teljes életútját felöleli, szokás „bölcsőtől a sírig” megközelítésnek is nevezni.

Környezetmarketing: Olyan felelősségteljes vállalati tevékenység, ahol a vállalat a környezetvédelemben fejlesztési növekedési lehetőséget lát, és azt érvényre juttatja minden tevékenységi területén, fenntartható módon. Azonban a környezetbarát, vagy zöldmarketing magában foglalja olyan termék vagy szolgáltatás előállítását is, amely környezeti előnyökkel rendelkezik és a vállalat versenyképességét javítja.

Fogyasztói környezettudatosság növelése: Nemzetközi vizsgálatok támasztják alá, hogy azon réteg, amely igazán elkötelezett a környezettudatosság iránt, elég szúk. Azonban ez a réteg hétköznapi tevékenységéhez tartozik a komposztálás, a szelektív hulladékgyűjtés, az energiafelhasználás csökkentése. Alapvetően magasabb árat is hajlandóak a termékekért adni, abban az esetben, ha az környezetbarát. Ez a réteg kellően nagyarányú ahhoz, hogy egyes vállalatok specializálódjanak igényeik kielégítésére.

Belső múködés újraszervezése: A kifelé történő kommunikáció mellett nagyon fontos, hogy a szervezet a belső múködését is környezettudatosan szervezze, és annak végrehajtásában a munkavállalók részt vehessenek. A belső, szervezeti működést, felépítést sok esetben szükséges részben, vagy akár teljesen újraszervezni, amennyiben a szervezet környezettudatosan kívánja tevékenységét folytatni. Ide tartoznak a kihelyezett szelektív hulladékgyújtő szigetek, energiatakarékos berendezések, világítóeszközök beszerzései is, de ide sorolható a humán erőforrás attitűdjének formálása különböző oktatások, tréningek, továbbképzések keretében, vagy a vezetői példamutató magatartás erősítése is. (Csutora, 2004)

\section{MIKRO- KIS- ÉS KÖZÉPVÁLLALKOZÁSOK, ILLETVE A NAGYVÁLLALATOK EMISSZIÓ CSÖKKENTÉSÉNEK LEHETŐSÉGEI}

A Magyarországon múködő vállalatok környezeti gyakorlatáról igen kevés rendszerezett információ áll rendelkezésre. Még az egyes iparágak szennyezési adatai sincsenek ágazati szinten aggregálva, holott ezen mutatókat a felügyelöségeknek be kell jelenteni. Még nehezebb az olyan kérdésekre válaszolni, amelyek a hazai ipar környezettudatosságának fokát firtatják.

A vállalati környezetvédelmi teljesítményről csak akkor kapható teljes kép, ha a szennyezést és az ökológiai hatásokat leíró mennyiségi mutatók mellett a vállalat alapfolyamatainak múködését jellemző mutatókat is kidolgoznak (pl. környezetvédelmi beruházások, környezetvédelmi képzés stb.), illetve ha kísérletet teszünk a vállalat ún. környezetvédelmi képességeinek felmérésére. Ez utóbbinak egyik legfőbb letéteményese a különböző vállalati környezetvédelmi intézmények rendszere (környezetvédelmi igazgató, bizottság, stratégia, képzés, az üzleti partnerek vizsgálata, kommunikáció stb.), egy kiépült környezetvédelmi irányítási rendszer. 
A vállalati környezetvédelmi teljesítmény értékelése tehát nem alapulhat csupán a termelés során felhasznált anyagok és energia, illetve a múködés okozta szennyezések mérésén, ezt ki kell egészítenie az olyan szemléletű mutatóknak, melyek azt értékelik, hogy a vállalat milyen mértékben integrálta a környezetvédelem szempontját általános irányítási rendszerébe és tevékenységébe.

A vállalatok számára tehát ma már elérhetőek az eszközök, de hogy melyiket választják és azt sikerül-e valóban beépíteniük a mindennapi gyakorlatba, az már koránt sem olyan egyértelmű. Leginkább a vállalat méretétől, tevékenységétől, nem utolsó sorban pedig a vezetőktől és a környezeti vagy CSR szakemberektől függ. Az eszközök legnagyobb előnye, hogy megfoghatóak, s hatékonyan szolgálják kitűzött céljukat. A korábban említett ISO 14001 szabvány és az EMAS rendelet például a környezettel kapcsolatos hatások jobb kézbentartását, a környezeti tényezők szisztematikus felmérését, célok kitűzését, programok és felelősök kinevezését célozza meg.

A környezetbarát irányítás szempontjából a vállalkozások lehetőségei a vállalkozás méretétől függően változhatnak. A korábban részletezett tevékenységek úgy, mint a tanúsítványok megszerzése, a szabványok bevezetése, az irányítási rendszerek, a termékcímkézés, hulladék-minimalizálás, öko-marketing bevezetése a környezeti kommunikáció, fenntarthatósági jelentés elkészítése, életciklus-elemzés, környezeti-teljesítményértékelés külön-külön és együttesen is alkalmazható a gyakorlatban, azonban ezek többnyire növelik a vállalkozások ráfordításait. Vannak olyan lehetőségek is, amelyek a ráfordításokat és költségeket képesek csökkenteni. Ide sorolhatóak az elektromos energia-, víz-, földgázfelhasználásból adódó emissziók, az adminisztratív területeken keletkező papírhulladék, a gépjármúvek káros anyag kibocsátásának csökkentésére vonatkozó lehetőségek.

A mikro-kis- és középvállalkozások mozgástere árbevételükből adódóan jóval kisebb, mint a nagyvállalatoké. Számukra többnyire a kisebb anyagi ráfordítással járó lehetőségek a mérvadóak, úgy mint:

- elektromos energia felhasználásának csökkentése,

- vízfelhasználás csökkentése,

- földgáz felhasználásának csökkentése,

- papírfelhasználás, papírhulladék keletkezésének csökkentése,

- tisztább termelés.

- hulladék-minimalizálás.

A nagyvállalatok ezzel szemben nagyobb anyagi ráfordításokkal járó lehetőségekkel is élhetnek:

- Környezetközpontú Irányítási Rendszer kidolgozása, tanúsítása

- továbbképzések a dolgozók és a vezetők számára

- öko-marketing, öko-címkézés

- környezetbarát termékfejlesztés

- életciklus-elemzés készítése

- géppark cseréje kevésbé környezetterhelő gépekre

- létesítményüzemeltetés (klímaberendezés, párásító berendezés, kompresszorok felhasználásának) optimalizálása

- szimbiózis kialakítása más nagyvállalatokkal (ipari ökológia)

\section{EGY IRODA KÁROSANYAG-KIBOCSÁTÁS CSÖKKENTÉSÉNEK LEHETŐSÉGEI}

Az alapvető különbség a vállalkozások méretétől függően az elért hatás mértéke. Nagy létszámmal múködő szervezet (nagyvállalat, multinacionális vállalat) csökkentési törekvéseinek hatása eredményesebbnek tűnhet, mint egy kisebb (mikro-kis és közép) vállalkozás intézkedése által elért emisszió-csökkenés. A következőkben a felelősségvállalás fontosságára egy irodai tevékenységet végző szervezet felépítésén keresztül világítok rá.

A kalkuláció során az alap épület egy $100 \mathrm{~m}^{2}$ területen lévő irodai tevékenységet folytató 5 alkalmazottal dolgozó szervezet telephelye, amely hagyományos izzókat használ, földgázzal fút, és elektromos árammal melegíti a vizet, energiatakarékos berendezéseket egyáltalán nem alkalmaz. 


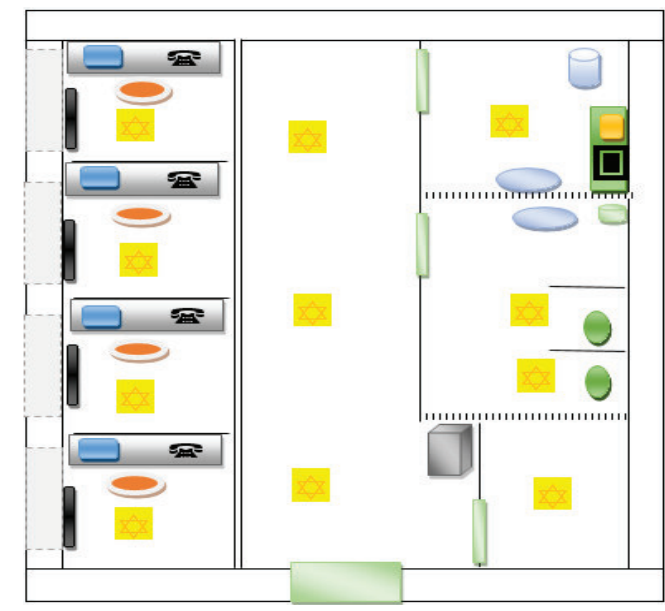

1. ábra: Az irodai tevékenységet végző szervezet telephelyének vázlata (saját szerkesztés - 2014)

A múszakrend 8-16 óráig tart, hétfőtől péntekig, éves 260 munkanappal számolva. Minden dolgozó rendelkezik egy számítógéppel, egy telefonnal, egy helyi megvilágítással, és az irodában van egy multifunkcionális nyomtató.
Az irodaházban a dolgozók rendelkezésére áll egy teakonyha, két mosdóhelyiség, és egy raktárhelyiség. Ezen helyiségek hagyományos izzóval vannak megvilágítva és a közlekedő folyosón is található megvilágítás (lásd 1. ábra)

\section{ÉVES DÍJAK ÉS A RÁFORDÍTÁSOK HATÁSA}

$\mathrm{Az}$ alábbi feltételek mellett az északmagyarországi régió átlagárait figyelembe véve az éves költségek, és a szén-dioxid kibocsátás alakulását szemlélteti a 1. táblázat.

A különböző energiatakarékos berendezések beszerzésének költségét a 3 . táblázat szemlélteti. Az eszközök beszerzése 11 darab $15 \mathrm{~W}$ teljesítményú izzóra, 3 darab perlátorra, 1 darab időkapcsoló órára, 1 darab fény-és mozgásérzékelő eszközre, és 1 tekercs hőtükör fóliára terjed ki.

\begin{tabular}{|c|c|c|c|c|c|c|c|}
\hline $\begin{array}{c}\text { Energia- } \\
\text { felhasználás }\end{array}$ & $\begin{array}{c}\text { Mennyi- } \\
\text { ség }\end{array}$ & $\mathbf{W}$ & $\mathbf{C O 2 e}$ & $\begin{array}{c}\text { CO2 } \\
\text { kibocsátás } \\
\mathbf{( k g )}\end{array}$ & $\begin{array}{c}\text { Éves } \\
\text { energiafelhasználás } \\
\mathbf{( k W )}\end{array}$ & $\begin{array}{c}\text { Megoszlás } \\
\text { (\%) }\end{array}$ & $\begin{array}{c}\text { Költség } \\
\text { (Ft) }\end{array}$ \\
\hline $\begin{array}{c}\text { Hagyományos } \\
\text { izzó }\end{array}$ & 11 & 60 & 0,375 & 579,15 & 1544,4 & $30,92 \%$ & 57417,68 \\
\hline PC & 4 & 35 & 0,375 & 109,2 & 291,2 & $5,83 \%$ & 10826,23 \\
\hline Monitor & 4 & 13,5 & 0,375 & 42,12 & 112,32 & $2,25 \%$ & 4175,831 \\
\hline $\begin{array}{c}\text { Fénymásoló- } \\
\text { nyomtató- } \\
\text { szkenner }\end{array}$ & 1 & 100 & 0,375 & 39 & 104 & $2,08 \%$ & 3866,511 \\
\hline telefon & 4 & 3 & 0,375 & 9,36 & 24,96 & $0,50 \%$ & 927,9625 \\
\hline kávéfőző & 1 & 1500 & 0,375 & 292,5 & 780 & $15,62 \%$ & 28998,83 \\
\hline hútő & 1 & 60 & 0,375 & 197,1 & 525,6 & $10,52 \%$ & 19540,75 \\
\hline mikro & 1 & 600 & 0,375 & 117 & 312 & $6,25 \%$ & 11599,53 \\
\hline $\begin{array}{c}\text { átfolyós } \\
\text { vízmelegítő }\end{array}$ & 1 & 2500 & 0,375 & 487,5 & 1300 & $26,03 \%$ & 48331,38 \\
\hline
\end{tabular}

1. táblázat: Villamos energia felhasználás költségei

Forrás: saját adatgyưjtés és szerkesztés, 2014

\begin{tabular}{|c|c|c|}
\hline & Éves dij előtte & Co2 kibocsátás előtte \\
\hline $\begin{array}{c}\text { Elektromos áram } \\
\text { felhasználás }\end{array}$ & 185684,7096 & 579 \\
\hline Vízfelhasználás & 4040 & 6,75 \\
\hline Gázfelhasználás & 62963,80795 & 1326,923077 \\
\hline
\end{tabular}

2. táblázat:

Éves díjak a ráfordítások előtt

Forrás: saját adatgyűjtés és szerkesztés, 2014

\begin{tabular}{|c|c|}
\hline & Beruházás összege (HUF) \\
\hline Izzócsere (60W-ról 15W-ra) & 14989 \\
\hline perlátorok & 7500 \\
\hline időkapcsoló óra & 2000 \\
\hline fény-és mozgásérzékelő & 5000 \\
\hline Hőtükör fólia & 2000 \\
\hline
\end{tabular}

3. táblázat:

zoldbolt.hu és zoldpolc.hu webshop 2014-ben érvényes árai

Forrás: saját adatgyújtés és szerkesztés, 2014 
A beruházások hatására az éves költségek alakulását a 4. táblázat mutatja, amely alapján megállapítható, hogy a közvetlenül a felhaszná lásból adódó éves megtakarítás megközelíti a
91 ezer Forintot, a számlázás során felmerülő egyéb, felhasználás alapján elszámolt költségekkel együtt pedig eléri a 120 ezer Forintot.

\begin{tabular}{|l|r|r|r|}
\hline & Éves dĩ elötte (HUF) & Éves díj utána (HUF) & Megtakarítás (HUF) \\
\hline Izzócsere (60W-ról 15W-ra) & 52541,82924 & 13091,04685 & 39450,78239 \\
\hline perlátor & 85022,265 & 68017,812 & 17004,453 \\
\hline idökapcsoló óra & 26538,11452 & 20254,38563 & 6283,728889 \\
\hline Fény-és mozgásérzékeló & 10605,816 & 2651,454 & 7954,362 \\
\hline Hötükörfolia & 151611,3385 & 131394,4103 & 20216,92823 \\
\hline & \multicolumn{2}{|l|}{ Összes } & $\mathbf{9 0 9 1 0 , 2 5 4 5 1}$ \\
\hline
\end{tabular}

4. táblázat: Éves díjak alakulása a ráfordítások hatására

Forrás: saját adatgyűjtés és szerkesztés, 2014

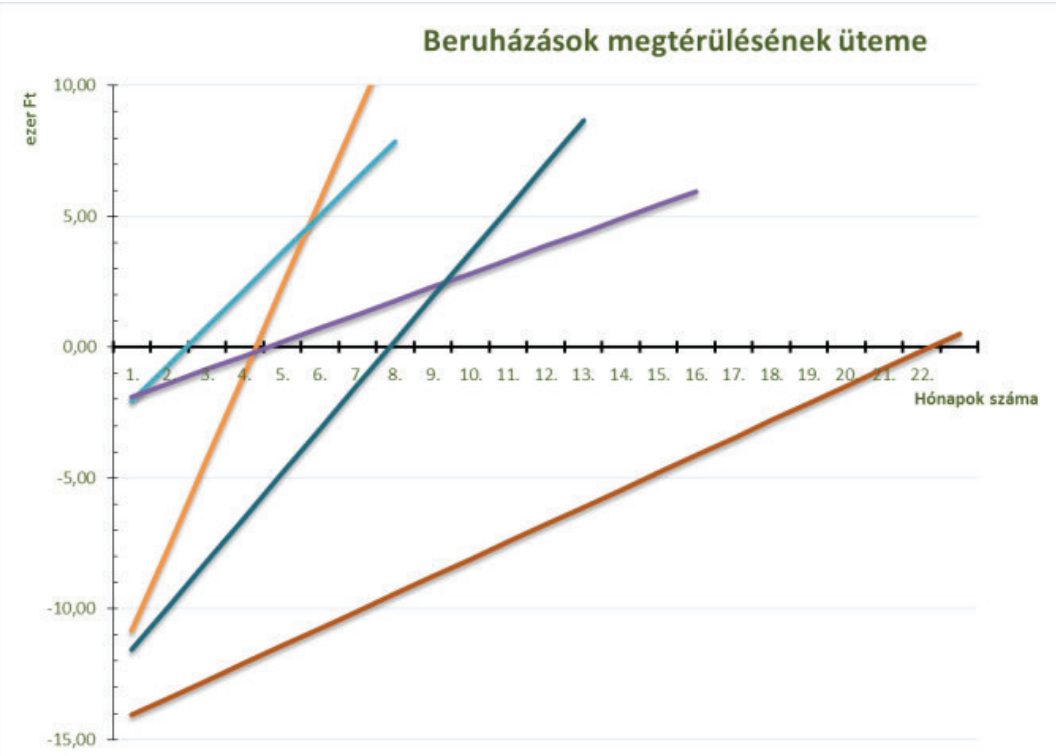

ZIzzócsere (60W-ról 15W-ra)

- perlátorok

—idökapcsoló óra

-fény-és mozgásérzékelő

—Hőtükör fólia

1. ábra: Emisszió csökkentésre irányuló beruházások megtérülése (saját szerk. 2014)

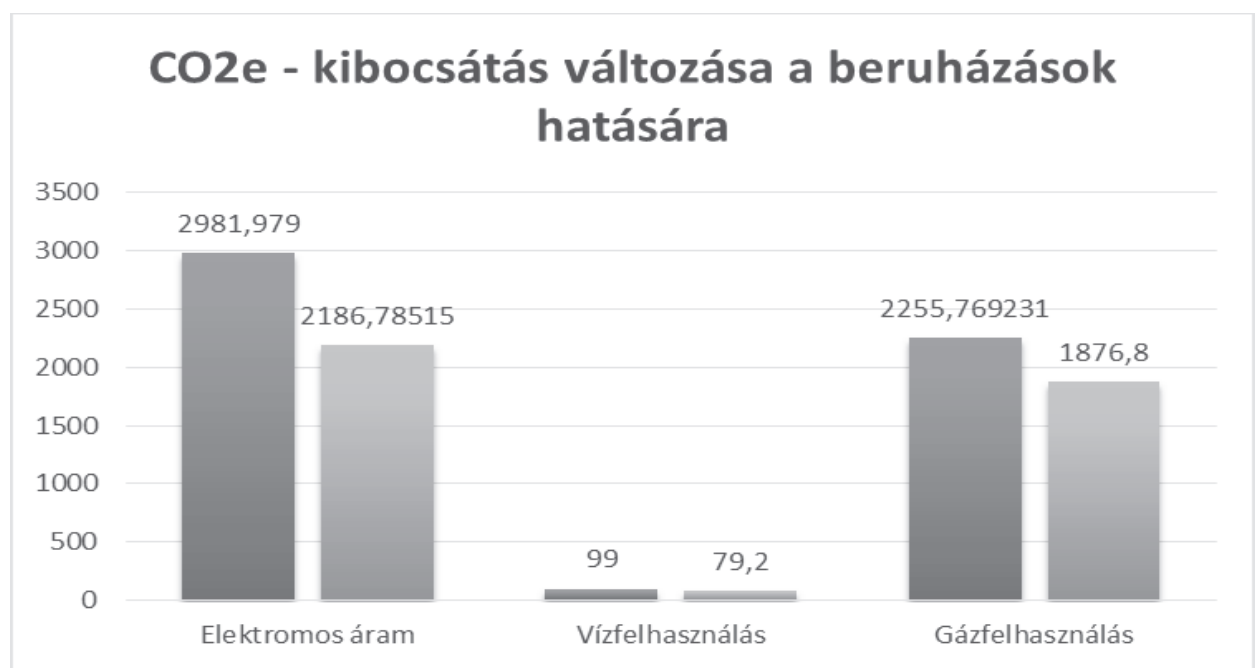

2. ábra: Szén-dioxid kibocsátás változása a beruházások hatására (saját szerk. 2014) 
A bemutatott ráfordítások a fény-és mozgásérzékelő kivételével 9 hónapon belül megtérülnek, így jelentős megtakarítást eredményeznek a szervezet számára. A 3. ábra szemlélteti a megtérülések időtartamát. Látható, hogy a vízperlátorok 2 hónapon belül, az időkapcsoló és az izzók cseréje pedig 4 hónapon belül megtérülnek, egy éven túli megtérüléssel jelen kalkulációban kizárólag a fény-és mozgásérzékelő eszköz beszerzése esetén számolhatunk.

A károsanyag-kibocsátás a ráfordításokkal és az energiafelhasználás csökkentésével párhuzamosan csökken, ahogyan azt a 4. ábra is mutatja. Egy év alatt az elektromos energiafelhasználásban közel $900 \mathrm{~kg}$, a vízfelhasználásban $20 \mathrm{~kg}$, és a földgázfelhasználásban $200 \mathrm{~kg}$ szén-dioxid kibocsátás csökkenés következik be. Ez megközelítőleg 1200 kg csökkenést jelent a szervezet éves karbon-lábnyomának kapcsán.

\section{FELHASZNÁLT FORRÁSOK}

[1.] A fenntarható fejlődés honlapja, 2014 http://www.ff3.hu/index.html

[2.] Bunyevácz József (2005): Környezetauditálás, Pécs http://ttk.pte.hu/biologia/zootax/Kornyezeti\%20audit/Kornyezet_auditalas_jegyzet.pdf

[3.] Csigéné Nagypál Noémi (2008): A vállalatok társadalmi felelősségvállalása és kapcsolódása a fenntarthatósághoz, Bp. Doktori Értekezés, p. 11-39

[4.] Csutora Mária - Kerekes Sándor (2004): A környezetbarát vállalatirányítás eszközei, Bp. KJK-KERSZÖV Jogi és Üzleti Kiadó Kft. p. 7-18., p. 22-138

[5.] Medvéné Dr. Szabad (2013): A fenntartható fejlődés gazdaságtana http://www.tankonyvtar.hu/hu/tartalom/tamop412A/0007_a4_1049_1051_fenntarthato fejl_2/3_4_vallalatok_tarsadalmi_felelossege_csr_es_fenntarthatosag_oYP4oka3rD2yFF3 7.html

[6.] Tóth Gergely (2007): A valóban felelős vállalat, KÖVET Egyesület p. 60-71 http://www.otlethid.hu/doc/VFV.pdf

[7.] Termékek (energiatakarékos izzó, vízperlátor, fény-és mozgásérzékelő, időkapcsoló óra, hőtükör fólia):

[1.] http://www.fenymasolopapir.com/termekeink

[2.] http://www.veddamagyart.info/

[3.] http://www.zoldpolc.hu/

[4.] http://www.zoldbolt.hu/ 